\title{
Wheat production performance in response to nitrogen sidedressing and molybdenum leaf application
}

\section{Desempenho produtivo do trigo em resposta a adubação nitrogenada de cobertura e foliar de molibdênio}

\author{
José Henrique Bizzarri Bazzo ${ }^{1 *}$; Felipe Pedote Fracalossi²; Claudemir Zucareli; \\ Inês Cristina de Batista Fonseca ${ }^{3}$; André Prechlak Barbosa ${ }^{4}$; Renê José dos Santos
}

\begin{abstract}
The application of nitrogen $(\mathrm{N})$ at the appropriate time can be effective for crop productivity, changing the grain yield by increasing yield components. Thus, new alternatives that enable a better application of $\mathrm{N}$ fertilizer are sought. The aim of this study was to evaluate the components of yield and productivity of wheat cultivated with different doses of $\mathrm{N}$ sidedressing and molybdenum (Mo) via leaf application, using two cultivars, CD 150 and Quartzo. The experiment was conducted in the crop years of 2013 and 2014. The experiment used a randomized, factorial 4 x 4 block design, with four replicates. Four doses of $\mathrm{N}$ sidedressing in the form of urea were applied $\left(0,30,60\right.$, and $\left.90 \mathrm{~kg} \mathrm{ha}^{-1}\right)$ during tillering. In the same period, leaf molybdic fertilizer was applied, using four dosages of Mo in the form of potassium molybdate $\left(0,20,40\right.$, and $\left.60 \mathrm{~g} \mathrm{ha}^{-1}\right)$. Grain number per ear (GNPE), 1,000-grain mass (TGM), hectoliter weight $(\mathrm{HW})$, and grain productivity (PROD) were evaluated. $\mathrm{N}$ fertilizer sidedressing did not promote the yield components of either of the wheat cultivars, although the GNPE of the Quartzo cultivar increased with increasing $\mathrm{N}$ doses in both crop years. The increase in $\mathrm{N}$ fertilizer increased the PROD of both wheat cultivars. The foliar application of Mo did not promote the yield components or wheat PROD of either cultivar. The HW was influenced by $\mathrm{N}$ and Mo rates, and was reduced in the absence of either of these fertilizer elements, indicating that the two nutrients were dependent on each other.
\end{abstract}

Key words: Nitrogen. Micronutrient. Productivity. Triticum aestivum L.

\section{Resumo}

A aplicação de nitrogênio $(\mathrm{N})$ na dose correta e no momento adequado pode aumentar sua eficiência na cultura do trigo, elevando o rendimento de grãos, por meio de alterações nos componentes de produção. $\mathrm{O}$ molibdênio (Mo) tem papel fundamental no metabolismo do $\mathrm{N}$ das plantas, atuando como cofator de enzimas responsáveis por sua assimilação. Objetivou-se avaliar os componentes de rendimento e a produtividade de grãos em trigo submetido a diferentes doses de $\mathrm{N}$ em cobertura e de adubação foliar com molibdato de potássio. O experimento foi conduzido nas safras 2013 e 2014, utilizando as cultivares CD150 e Quartzo, sob o delineamento experimental de blocos casualizados, em esquema fatorial 4 x 4 , com quatro repetições. $\mathrm{Na}$ fase de perfilhamento foram aplicadas quatro doses de $\mathrm{N}$ em

1 Discente do Curso de Doutorado do Programa de Pós-Graduação em Agronomia, Universidade Estadual de Londrina, UEL, Londrina, PR, Brasil. E-mail: agro.bazzo@gmail.com

2 Discente do Curso de Mestrado do Programa de Pós-Graduação em Ciência de Alimentos, UEL, PR, Brasil. E-mail: felipelossi@ hotmail.com

3 Profs. Drs., Departamento de Agronomia, UEL, Londrina, PR, Brasil. E-mail: claudemircca@uel.br; inescbf@uel.br

4 Discente do Curso de Doutorado do Programa de Pós-Graduação em Agronomia, UEL, Londrina, PR, Brasil. E-mail: andreprechlak@gmail.com

5 Eng ${ }^{\text {O Agr }}$, Ubyfol, Londrina, PR, Brasil. E-mail: rene.santos@ubyfol.com.br

Author for correspondence 
cobertura $\left(0,30,60\right.$ e $\left.90 \mathrm{~kg} \mathrm{ha}^{-1}\right)$, na forma de ureia, e também quatro doses de molibidênio $(0,20,40$ e $\left.60 \mathrm{~g} \mathrm{ha}^{-1}\right)$ via foliar na forma de molibidato de potássio. Foram avaliados o número de grãos por espiga (NGE), a massa de mil grãos (MMG), o peso hectolítrico (PH) e a produtividade de grãos (PROD). A adubação nitrogenada de cobertura não favorece os componentes de produção de ambas cultivares de trigo, exceto o número de grãos por espiga da cultivar Quartzo, que aumenta com o incremento das doses de $\mathrm{N}$ nas duas safras. $\mathrm{O}$ aumento da fertilização nitrogenada eleva a produtividade de grãos de trigo das duas cultivares. A aplicação foliar de Mo não favorece os componentes do rendimento e a produtividade de grãos de trigo de ambas cultivares. A interação entre as doses $\mathrm{N}$ e Mo afeta a característica peso hectolítrico, com redução desta variável na ausência de adubação de um dos elementos.

Palavras-chave: Nitrogênio. Micronutriente. Produtividade. Triticum aestivum L.

\section{Introduction}

Wheat comprises approximately $30 \%$ of the world's grain production due to the high consumption of its derivatives (SOUZA et al., 2013). In Brazil, wheat cultivation is concentrated in the southern states, but has been spreading to the central-west and southeast regions (PIETROSOUZA et al., 2013).

The full potential of wheat production is achieved with the use of nitrogen $(\mathrm{N})$ fertilizer, since it is, quantitatively, the most important element for this plant (TEIXEIRA FILHO et al., 2007) and positively affects the productivity and quality of grains (MEGDA et al., 2009).

Brazilian soils do not provide the increment of $\mathrm{N}$ required by wheat plants (TEIXEIRA FILHO et al., 2010), and since this element is responsible for a series of metabolic functions that determine adequate growth and development of plants (YANO et al., 2005), it is essential to supplement the soil with $\mathrm{N}$ fertilizers.

In this context, the literature recommends installments of $\mathrm{N}$ fertilizer, making part of the nutrient available during sowing and the remainder available on the soil cover, taking into account the previous culture. In the state of Paraná, $\mathrm{N}$ fertilizer application is recommended at the tillering stage of culturing (CUNHA; CAIERÃO, 2015). Peruzzo (2000) reported that the provision of $\mathrm{N}$ in this period increases the efficiency with which wheat can use this nutrient, with an increase in grain yield.
According to Martini Junior et al. (2011) the efficiency of $\mathrm{N}$ utilization by the plant is influenced by the cultivar, and may differ by the quality of tillering, culture cycle, and potential grain production. The same authors reported that these factors might cause distinct responses depending on the stage and doses in which $\mathrm{N}$ is applied. When working with different genotypes Teixeira Filho et al. (2007) observed that applying $\mathrm{N}$ increased the number of ears per area, productivity, and 1000 -grain mass of all cultivars.

$\mathrm{N}$ is absorbed in nitric form, in order to be reduced into ammonia in the plant through the action of nitrate reductase enzyme. The activity of these enzyme is highly dependent on Mo (BULL, 1993). Thus, Mo plays a fundamental role in the incorporation of $\mathrm{N}$ into the plant, acting as a cofactor of enzymes responsible for $\mathrm{N}$ assimilation (MARTENS; WESTERMANN, 1991).

Ferreira et al. (2001) observed that Mo fertilizer in corn culture increased the content of proteins in grains by 3\%. According to Marschner (1995), the positive influence of Mo on protein content may be due to its effect on the metabolic processing of $\mathrm{N}$, by increasing the activity of nitrate reductase and, consequently, greater conversion of $\mathrm{N}$ into proteins.

In this context, this study aimed to assess the yield components and grain productivity of wheat cultures subjected to different doses of $\mathrm{N}$ applied to the soil cover and leaves fertilized with potassium molybdate. 


\section{Materials and Methods}

Two experiments were performed in two agricultural years (2013 and 2014) at the farm school of the State University of Londrina (FAZESC-UEL), in the municipality of Londrina-PR. The soil was a eutroferric red latosol (EMBRAPA, 2006), located at the geographic coordinates $23^{\circ} 23^{\prime} \mathrm{S}$ and $51^{\circ} 11^{\prime} \mathrm{W}$, at an altitude of $566 \mathrm{~m}$. The climate of the region is of Cfa type, described as humid subtropical with hot summers according to the Köppen classification. The data for pluvial precipitation and temperature during the experimental periods were obtained from the meteorological station at the Agronomy Institute of Paraná (Figure 1).

Figure 1. Average temperature and pluvial precipitation for the 10-day periods when experiments were performed. Londrina-PR, 2013 and 2014.

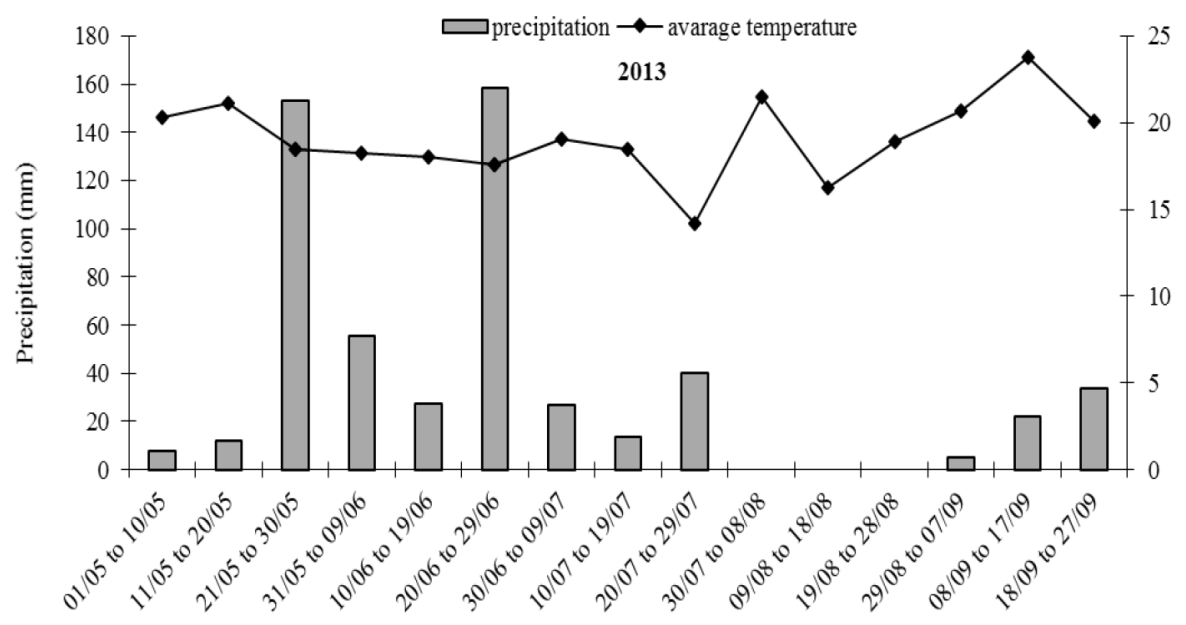

Period of the month

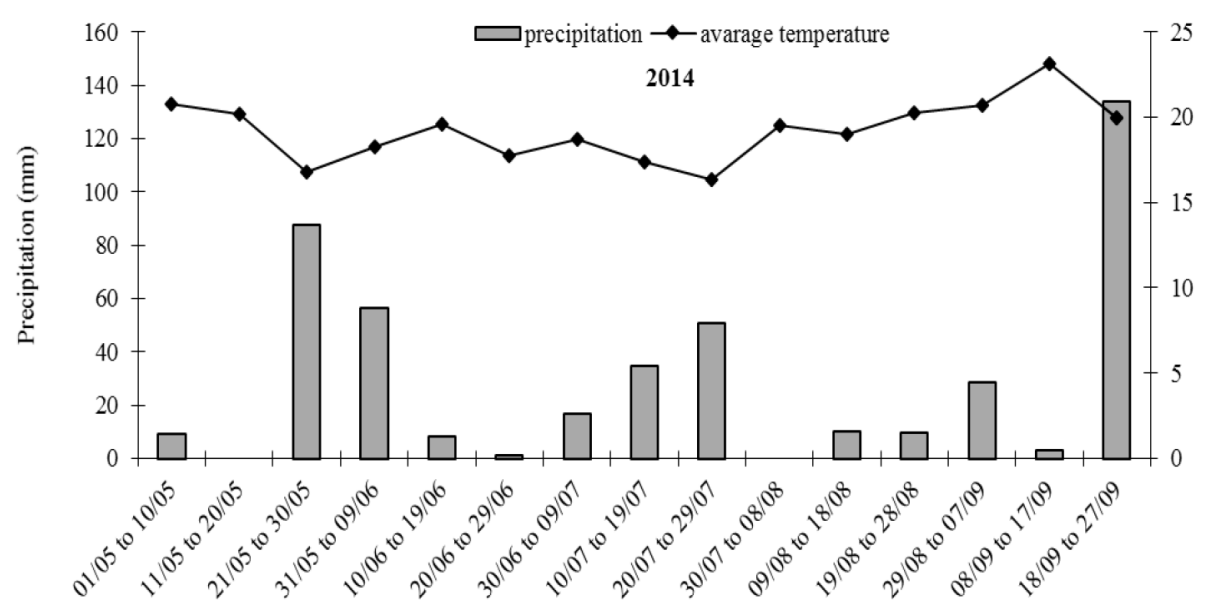

The chemical characteristics of the soil were defined before performing the experiment at depths of $0-10 \mathrm{~cm}$ and $10-20 \mathrm{~cm}$. In the agricultural year 2013, conditions at $0-10 \mathrm{~cm}$ were: $\mathrm{pH}\left(\mathrm{CaCl}_{2} 0.01\right.$ mol L-1) $5.49,3.94 \mathrm{cmol}_{\mathrm{c}} \mathrm{dm}^{-3}$ of $\mathrm{H}+\mathrm{Al}^{3+}, 5.4 \mathrm{cmol}_{\mathrm{c}}$ $\mathrm{dm}^{-3}$ of $\mathrm{Ca}^{2+}, 1.53 \mathrm{cmol}_{\mathrm{c}} \mathrm{dm}^{-3}$ of $\mathrm{Mg}^{2+}, 0.87 \mathrm{cmol}_{\mathrm{c}}$ $\mathrm{dm}^{-3}$ of $\mathrm{K}^{+}, 11.41 \mathrm{mg} \mathrm{dm}^{-3}$ of $\mathrm{P}$, and $29.64 \mathrm{~g} \mathrm{dm}^{-3}$ of organic matter. For soil depth $10-20 \mathrm{~cm}$, conditions 
were: $\mathrm{pH}\left(\mathrm{CaCl}_{2} 0.01 \mathrm{~mol} \mathrm{~L}^{-1}\right) 5.49,3.66 \mathrm{cmol}_{\mathrm{c}} \mathrm{dm}^{-3}$ of $\mathrm{H}+\mathrm{Al}^{3+}, 4.91 \mathrm{cmol}_{\mathrm{c}} \mathrm{dm}^{-3}$ of $\mathrm{Ca}^{2+}, 1.37 \mathrm{cmol}_{\mathrm{c}} \mathrm{dm}^{-3}$ of $\mathrm{Mg}^{2+}, 0.57 \mathrm{cmol}_{\mathrm{c}} \mathrm{dm}^{-3}$ of $\mathrm{K}^{+}, 8.08 \mathrm{mg} \mathrm{dm}^{-3}$ of $\mathrm{P}$, and $27 \mathrm{~g} \mathrm{dm}^{-3}$ of organic matter. For the agricultural year 2014, conditions at $0-10 \mathrm{~cm}$ were: $\mathrm{pH}\left(\mathrm{CaCl}_{2}\right.$ $0.01 \mathrm{~mol} \mathrm{~L}^{-1}$ ) 5.40, $4.96 \mathrm{cmol}_{\mathrm{c}} \mathrm{dm}^{-3}$ of $\mathrm{H}+\mathrm{Al}^{3+}, 7.9$ $\mathrm{cmol}_{\mathrm{c}} \mathrm{dm}^{-3}$ of $\mathrm{Ca}^{2+}, 0.9 \mathrm{cmol}_{\mathrm{c}} \mathrm{dm}^{-3}$ of $\mathrm{Mg}^{2+}, 0.91$ $\mathrm{cmol}_{\mathrm{c}} \mathrm{dm}^{-3}$ of $\mathrm{K}^{+}, 1.58 \mathrm{mg} \mathrm{dm}^{-3}$ of $\mathrm{P}$, and $26.90 \mathrm{~g}$ $\mathrm{dm}^{-3}$ of organic matter. For soil depth of 10-20 cm, conditions were: $\mathrm{pH}\left(\mathrm{CaCl}_{2} 0.01 \mathrm{~mol} \mathrm{~L}^{-1}\right) 5.4,4.61$ $\mathrm{cmol}_{\mathrm{c}} \mathrm{dm}^{-3}$ of $\mathrm{H}+\mathrm{Al}^{3+}, 7.3 \mathrm{cmol}_{\mathrm{c}} \mathrm{dm}^{-3}$ of $\mathrm{Ca}^{2+}, 1.2$ $\mathrm{cmol}_{\mathrm{c}} \mathrm{dm}^{-3}$ of $\mathrm{Mg}^{2+}, 0.81 \mathrm{cmol}_{\mathrm{c}} \mathrm{dm}^{-3}$ of $\mathrm{K}^{+}, 0.76 \mathrm{mg}$ $\mathrm{dm}^{-3}$ of $\mathrm{P}$, and $20.15 \mathrm{~g} \mathrm{dm}^{-3}$ of organic matter.

The experiments were conducted under a direct seeding system, in an area previously occupied by corn culture. Based on soil chemical characteristics, the basic mineral fertilizer in the seed inoculation sulcus was calculated, and was constant for all treatments. In the 2013 harvest, this was $12 \mathrm{~kg} \mathrm{ha}^{-1}$ of $\mathrm{N}, 42 \mathrm{~kg} \mathrm{ha}^{-1}$ of $\mathrm{P}_{2} \mathrm{O}_{5}$, and $24 \mathrm{~kg} \mathrm{ha}^{-1}$ of $\mathrm{K}_{2} \mathrm{O}$, using the ratio $4: 14: 8$. In the 2014 harvest, this was $24 \mathrm{~kg} \mathrm{ha}^{-1}$ of $\mathrm{N}, 84 \mathrm{~kg} \mathrm{ha}^{-1}$ of $\mathrm{P}_{2} \mathrm{O}_{5}$, and $48 \mathrm{~kg} \mathrm{ha}^{-1}$ of $\mathrm{K}_{2} \mathrm{O}$, using the ratio 8:28:16.

Two wheat cultivars with different agronomical characteristics and industrial qualities were analyzed, CD 150 (early cycle, moderate resistance to lodging, and of enhancer type industrial quality) and Quartzo (mid cycle, moderate resistance to lodging, and of bread type industrial quality).

The experimental design was in randomized blocks, with 16 treatments per cultivar, arranged in a 4 x 4 factorial scheme. This corresponded to four doses of $\mathrm{N}$ fertilizer in the form of urea applied to soil cover $\left(0,30,60\right.$, and $\left.90 \mathrm{~kg} \mathrm{ha}^{-1}\right)$, combined with four doses of Mo in the form potassium molybdate applied via the leaves $\left(0,20,40\right.$, and $\left.60 \mathrm{~g} \mathrm{ha}^{-1}\right)$, with four replicates.

The soil cover $\mathrm{N}$ fertilizer, in the form of ammonium sulfate $(21 \% \mathrm{~N})$, was applied by spreading during the tillering phase (phenological stage 2, Feekes scale). The Mo fertilizer, in the form of potassium molybdate, was applied to leaves in the same period with a $\mathrm{CO}_{2}$ pressurized sprayer, at concentrations of $14 \%$ of Mo and $12 \%$ of $\mathrm{K}_{2} \mathrm{O}$, and at a density of $1.4 \mathrm{~g} \mathrm{~mL}^{-1}$.

The wheat cultivars were sowed mechanically on May 8, 2013 and May 7, 2014 at a density of 300 viable seeds per square meter. The plots comprised 14 lines, $6 \mathrm{~m}$ in length, with $0.17 \mathrm{~m}$ spacing between lines. The six central lines with $5.1 \mathrm{~m}^{2}$ useful area were analyzed per parcel.

Grains were harvested after the culture reached maturation (phenological stage 11.4, Feekes scale). The following evaluations were performed: a) grain number per ear (GNPE - obtained by counting the number of grains in 10 ears of wheat collected randomly in each plot); b) 1000-grain mass (TGM - obtained by counting and weighing two replicates in 100 grains of wheat per plot. The average of these values was multiplied by 10 to obtain the value corresponding to the 1000-grain mass); c) hectoliter weight (HW - determined by weighing a known volume [250 $\mathrm{mL}$ ] of a sample using the Dalle Molle ${ }^{\circledR}$ instrument, and transforming the result into the standard unit $\left.\left[\mathrm{kg} \mathrm{hL}^{-1}\right]\right)$; d) grain productivity ( $\mathrm{PROD}$ - determined by harvesting the plants contained in the useful area of the plot. After mechanical threshing, the grains were weighed and the data transformed into $\mathrm{kg} \mathrm{ha}^{-1}$ at $13 \%$ humidity).

For each cultivar, normality and homogeneity of error were assessed, and subsequently, cultivation years were combined in a variance analysis. The effects of $\mathrm{N}$ and Mo doses were studied using unfolding orthogonal polynomials until the $2^{\text {nd }}$ grade.

\section{Results and Discussion}

For cultivar CD 150, a significant interaction between year and doses of Mo for GNPE was observed. On the other hand, for the variables TGM and PROD, an isolated effect of $\mathrm{N}$ doses in the soil cover was observed. For the HW, there was an interactive effect between year and $\mathrm{N}$ doses, and between $\mathrm{N}$ and Mo doses. We observed a significant effect of cultivation year for the characteristics 
TGM and PROD, with the highest values of the harvest occurring in 2014 (Table 1).

For the cultivar Quartzo, there was a significant interaction between year and $\mathrm{N}$ doses for GNPE. An isolated effect of $\mathrm{N}$ in the soil cover was observed for TGM, HW, and PROD, and of Mo doses for TGM and HW. There was a significant effect of year for TGM, HW, and PROD in this cultivar, with the highest values at harvest occurring in 2014 (Table 2).

Table 1. Values of mean squared from variance analysis of cultivar CD 150 for the characteristics assessed according to doses of N applied to the soil cover and Mo to leaves. Londrina-PR, 2013 and 2014.

\begin{tabular}{|c|c|c|c|c|c|}
\hline \multirow{2}{*}{ SOURCE OF VARIATION } & \multirow{2}{*}{ GL } & \multicolumn{4}{|c|}{ CHARACTERISTICS } \\
\hline & & GNPE & TGM (g) & $\mathrm{HW}\left(\mathrm{kg} \mathrm{hL}^{-1}\right)$ & PROD $\left(\mathrm{kg} \mathrm{ha}^{-1}\right)$ \\
\hline Year $(\mathrm{Y})$ & 1 & $157.22 *$ & $591.85 * *$ & $934.36^{* *}$ & $22,377,456.26^{* *}$ \\
\hline Nitrogen $(\mathrm{N})$ & 3 & $30.94^{\mathrm{ns}}$ & $22.44 * *$ & $1.59^{\mathrm{ns}}$ & $3,971,846.35^{* *}$ \\
\hline Molybdenum (Mo) & 3 & $161.73 * *$ & $1.92^{\mathrm{ns}}$ & $0.43^{\mathrm{ns}}$ & $310,046.99^{\mathrm{ns}}$ \\
\hline $\mathrm{Y} \times \mathrm{N}$ & 3 & $76.58^{\mathrm{ns}}$ & $4.78^{\mathrm{ns}}$ & $3.37 * *$ & $221,162.73^{\mathrm{ns}}$ \\
\hline $\mathrm{Y} \times \mathrm{Mo}$ & 3 & $107.89 *$ & $1.22^{\mathrm{ns}}$ & $2.13^{\mathrm{ns}}$ & $58,255.81^{\text {ns }}$ \\
\hline $\mathrm{N} \times \mathrm{Mo}$ & 9 & $50.46^{\mathrm{ns}}$ & $2.04^{\mathrm{ns}}$ & $2.16^{* *}$ & $363,611.31^{\mathrm{ns}}$ \\
\hline $\mathrm{Y} \times \mathrm{N} \times \mathrm{Mo}$ & 9 & $22.86^{\mathrm{ns}}$ & $3.60^{\mathrm{ns}}$ & $1.05^{\mathrm{ns}}$ & $292,539.83^{\mathrm{ns}}$ \\
\hline Block (Y) & 6 & $72.22^{\mathrm{ns}}$ & $1.92^{\mathrm{ns}}$ & $4.07 * *$ & $182,736.89^{\text {ns }}$ \\
\hline Error & 90 & 33.02 & 2.07 & 0.91 & $203,020.25$ \\
\hline 2013 & & & $28.78 \mathrm{~b}$ & & $1696.34 \mathrm{~b}$ \\
\hline 2014 & & & $33.08 \mathrm{a}$ & & $2532.58 \mathrm{a}$ \\
\hline $\mathrm{CV}(\%)$ & & 15.86 & 4.66 & 1.21 & 21.31 \\
\hline
\end{tabular}

GNPE: grain number per ear; TGM: 1000-grain mass; HW: hectoliter weight; PROD: grain productivity; ${ }^{2},{ }^{*},{ }^{* *}$ : not significant and significant at $5 \%$ and $1 \%$ of probability by the F-test.

Averages followed by the same letter in the column are not significantly different by the F-test of the variance analysis.

Table 2. Values of mean squared from the variance analysis of cultivar Quartzo for the characteristics evaluated according to the $\mathrm{N}$ doses applied to the soil cover and Mo to leaves. Londrina-PR, 2013 and 2014.

\begin{tabular}{|c|c|c|c|c|c|}
\hline \multirow{2}{*}{ SOURCE OF VARIATION } & \multirow{2}{*}{ GL } & \multicolumn{4}{|c|}{ CHARACTERISTICS } \\
\hline & & GNPE & TGM (g) & $\mathrm{HW}\left(\mathrm{kg} \mathrm{hL}^{-1}\right)$ & PROD $\left(\mathrm{kg} \mathrm{ha}^{-1}\right)$ \\
\hline Year (Y) & 1 & $576.43 * *$ & $37.63 * *$ & $13.23 * *$ & $8,283,579.46^{* *}$ \\
\hline Nitrogen $(\mathrm{N})$ & 3 & $52.08^{\mathrm{ns}}$ & $90.45 * *$ & $9.41 * *$ & $716,161.32 * *$ \\
\hline Molybdenum (Mo) & 3 & $31.16^{\mathrm{ns}}$ & $4.82 *$ & $2.29 *$ & $162,257.61^{\mathrm{ns}}$ \\
\hline $\mathrm{Y} \times \mathrm{N}$ & 3 & $86.41 *$ & $0.64^{\text {ns }}$ & $1.63^{\text {ns }}$ & $106,458.47^{\text {ns }}$ \\
\hline $\mathrm{Y} \times \mathrm{Mo}$ & 3 & $32.57^{\mathrm{ns}}$ & $1.07^{\mathrm{ns}}$ & $0.20^{\mathrm{ns}}$ & $30,486.30^{\text {ns }}$ \\
\hline $\mathrm{N} \times \mathrm{Mo}$ & 9 & $35.87^{\mathrm{ns}}$ & $1.82^{\mathrm{ns}}$ & $1.51^{\mathrm{ns}}$ & $149,309.37^{\mathrm{ns}}$ \\
\hline $\mathrm{Y} \times \mathrm{N} \times \mathrm{Mo}$ & 9 & $22.44^{\mathrm{ns}}$ & $0.62^{\mathrm{ns}}$ & $0.83^{\mathrm{ns}}$ & $210,505.51^{\mathrm{ns}}$ \\
\hline Block (Y) & 6 & $74.37 *$ & $13.98 * *$ & $6.94 * *$ & $373,600.43^{*}$ \\
\hline Error & 90 & 25.61 & 1.43 & 0.88 & $111,902.44$ \\
\hline 2013 & & & $30.05 \mathrm{~b}$ & $75.43 \mathrm{~b}$ & $1716.62 \mathrm{~b}$ \\
\hline 2014 & & & $31.13 \mathrm{a}$ & $76.07 \mathrm{a}$ & $2225.40 \mathrm{a}$ \\
\hline CV $(\%)$ & & 13.70 & 3.91 & 1.24 & 16.97 \\
\hline
\end{tabular}

GNPE: grain number per ear; TGM: 1000-grain mass; HW: hectoliter weight; PROD: grain productivity; ${ }^{\text {ns }},{ }^{*},{ }^{* *}$ : not significant and significant at $5 \%$ and $1 \%$ of probability by the F-test.

Averages followed by the same letter in the column are not significantly different by the F-test of the variance analysis. 
During the entire cycle of the culture, the pluvial precipitation was $555.9 \mathrm{~mm}$ in 2013, and 450.3 $\mathrm{mm}$ in 2014 (Figure 1). In both of these years, the volumes were considered adequate, but uneven in distribution, in particular in the grain filling phase in 2013, which contributed to the lower values obtained for some of the characteristics assessed for both cultivars in this harvest (Tables 1 and 2).

In the 2013 harvest of cultivar CD 150, the GNPE followed a decreasing linear function with increase of the Mo fertilizer. In contrast, there was no effect of Mo doses in the 2014 harvest (Figure 2a). The reduction may have been due to more effective tillering, which could have contributed to a greater number of ears per area and, as a consequence, a lower GNPE. In the $40 \mathrm{~g} \mathrm{ha}^{-1}$ dose of Mo, GNPE was higher in the 2014 harvest than the 2013 harvest. Ferreira et al. (2003) studied the effect of four doses $\left(0,40,80\right.$, and $\left.120 \mathrm{~g} \mathrm{ha}^{-1}\right)$ of Mo fertilizer (sodium molybdate) on the components of yield and grain productivity in a variety of beans known in Brazil as Meia-Noite. They observed that an increment in Mo doses resulted in an increase of pod numbers per area, and a decrease in the number of grains per pod, which is in agreement with our results. Nevertheless, Zoz et al. (2012) assessed the effect of source (Omega Molibdênio 220 ${ }^{\circledR}$ ) and Mo doses $\left(0,13.8,27.6\right.$, and $\left.55.2 \mathrm{~g} \mathrm{ha}^{-1}\right)$ on the agronomical characteristics and productivity of wheat and did not observe significant effects on this component of production.

For the cultivar Quartzo, the GNPE followed increasing linear and quadratic functions for the 2013 and 2014 harvests, respectively, in response to the $\mathrm{N}$ fertilizer in the soil cover. In 2013, the increment of $\mathrm{N}$ doses increased GNPE and, in 2014, the highest value for this variable (35.75) was obtained with a dose estimated as $55.57 \mathrm{~kg} \mathrm{ha}^{-1}$ of $\mathrm{N}$ (Figure 2b). According to Marschner (1995), high doses of $\mathrm{N}$ increased the gibberellic acid content, resulting in protein synthesis and more flowering, with the result that the plant increased the number of flowers per ear, which could explain the increase in GNPE observed in this study. Theago et al. (2014), observed a quadratic effect of $\mathrm{N}$ doses on this component, with the maximum point occurring at an application estimated as $128 \mathrm{~kg} \mathrm{ha}^{-1}$ of N. Such different responses in this study may be related to the different materials used, the conditions of the soil, and the quantity and distribution of rains in cultivation years, which were better in the 2013 harvest, that together could have favored better use of $\mathrm{N}$ by the plants, and the increased GNPE as a response to this nutrient.

The highest values of GNPE were obtained in 2013, except at the $30 \mathrm{~kg} \mathrm{ha}^{-1}$ dose of $\mathrm{N}$ (Figure 2b), which could be explained by the better hydric conditions that occurred in this year (Figure 1) during the reproductive phase of the culture when the potential for grain formation is developed.

The TGM in both cultivars decreased with the increase in $\mathrm{N}$ concentrations applied to the soil cover (Figure $3 \mathrm{a}$ and 3b). Espindula et al. (2010) obtained similar results by testing two cultivars of wheat (BRS 210 and Pioneiro) and five $\mathrm{N}$ doses in soil cover $\left(40,60,80,100\right.$, and $\left.120 \mathrm{~kg} \mathrm{ha}^{-1}\right)$. However, Teixeira Filho et al. (2007) reported that the TGM of wheat followed a quadratic function with the maximum point occurring at a dose of $68 \mathrm{~kg} \mathrm{ha}^{-1}$ of N. According to Prando et al. (2013), the decrease of the TGM may have occurred due to the increase in the number of grains and tilling per area with the increase in $\mathrm{N}$ doses. High concentrations of $\mathrm{N}$ may promote the production of a higher number of grains per wheat ears, forming smaller sized grains, due to a filling deficiency caused by competition for photoassimilates and a concomitant decrease in the single mass of grains (CAZETTA et al., 2007). 
Figure 2. Grain number per ear of cultivar CD 150 in response to the molybdenum doses via leaves (a) and Quartzo in response to the nitrogen doses in the soil cover (b). Londrina-PR, 2013 and 2014.
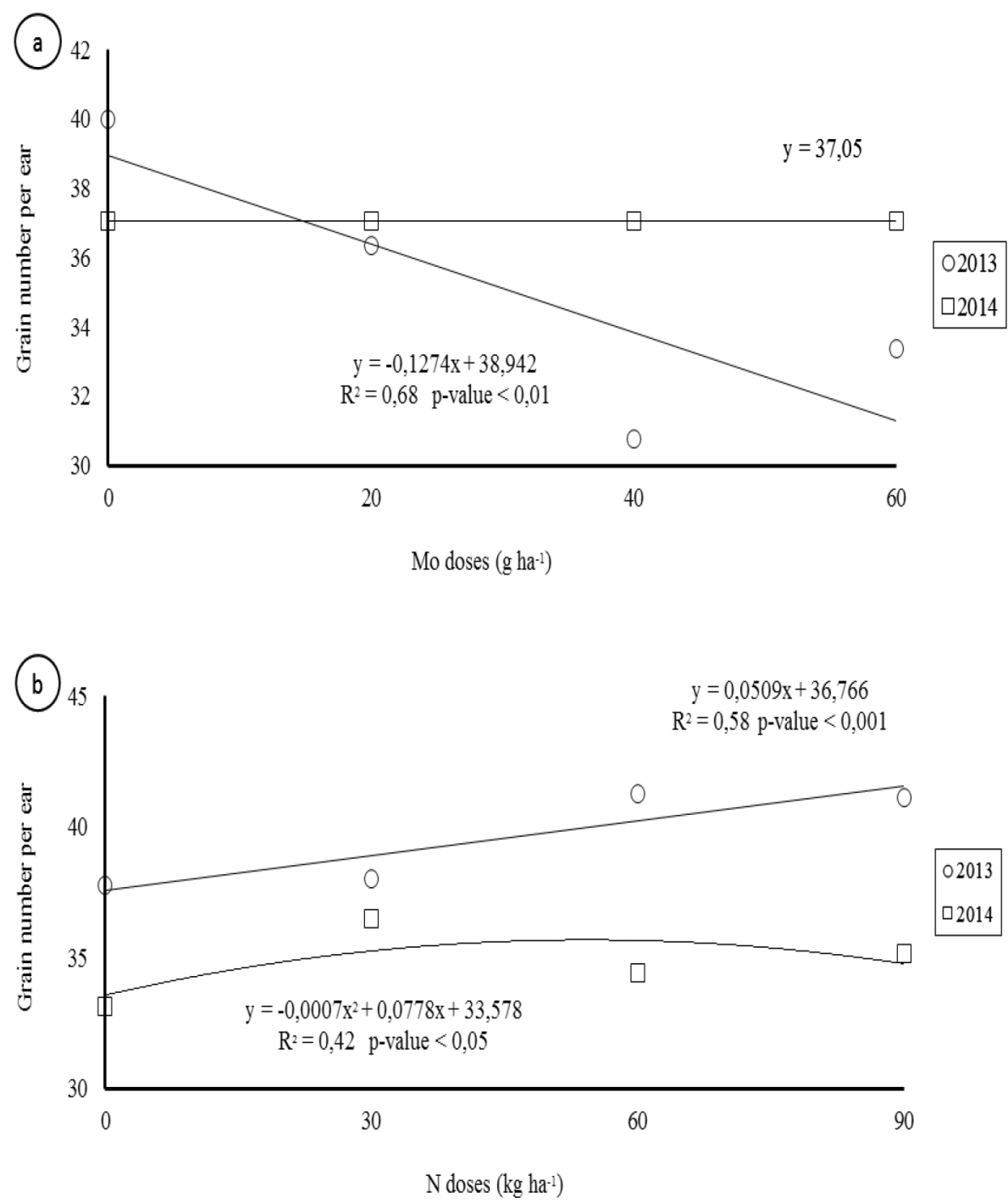

For the cultivar Quartzo, we also observed an isolated effect of doses of Mo for the TGM, with the values following a quadratic function and a minimum mass (30.16 g) occurring at a dose estimated as 35.5 $\mathrm{g} \mathrm{ha}^{-1}$ of Mo applied to the leaves (Figure 3c). In the study by Zoz et al. (2012), the TGM of wheat did not significantly differ according to Mo doses. The authors reported that this was probably a result of the increase in number of ears per square meter with increasing doses of Mo. This result reflects indirectly the number of viable tillings, which may be considered as physiological drains that promote the re-distribution of assimilates between drains in the plant.

The HW of cultivar CD 150 presented a different response between harvests, with increasing linear and quadratic functions observed for 2013 and 2014, respectively (Figure 4a). In the second year, the maximum value of $\mathrm{HW}\left(81.99 \mathrm{~kg} \mathrm{hL}^{-1}\right)$ was obtained at a dose estimated as $43 \mathrm{~kg} \mathrm{ha}^{-1}$ of $\mathrm{N}$. The lower HW of the 2013 harvest, compared to 2014, for all $\mathrm{N}$ doses was related to the occurrence of rains near the harvest period, and the low volume of rains during the grain filling phase in 2013 (Figure 1) that might have compromised the density of the grains. 
Figure 3. 1000-grain mass of cultivars CD 150 (a) and Quartzo (b) in response to nitrogen doses in the soil cover and of cultivar Quartzo (c) in response to the doses of molybdenum applied via leaves. Londrina-PR, 2013 and 2014.
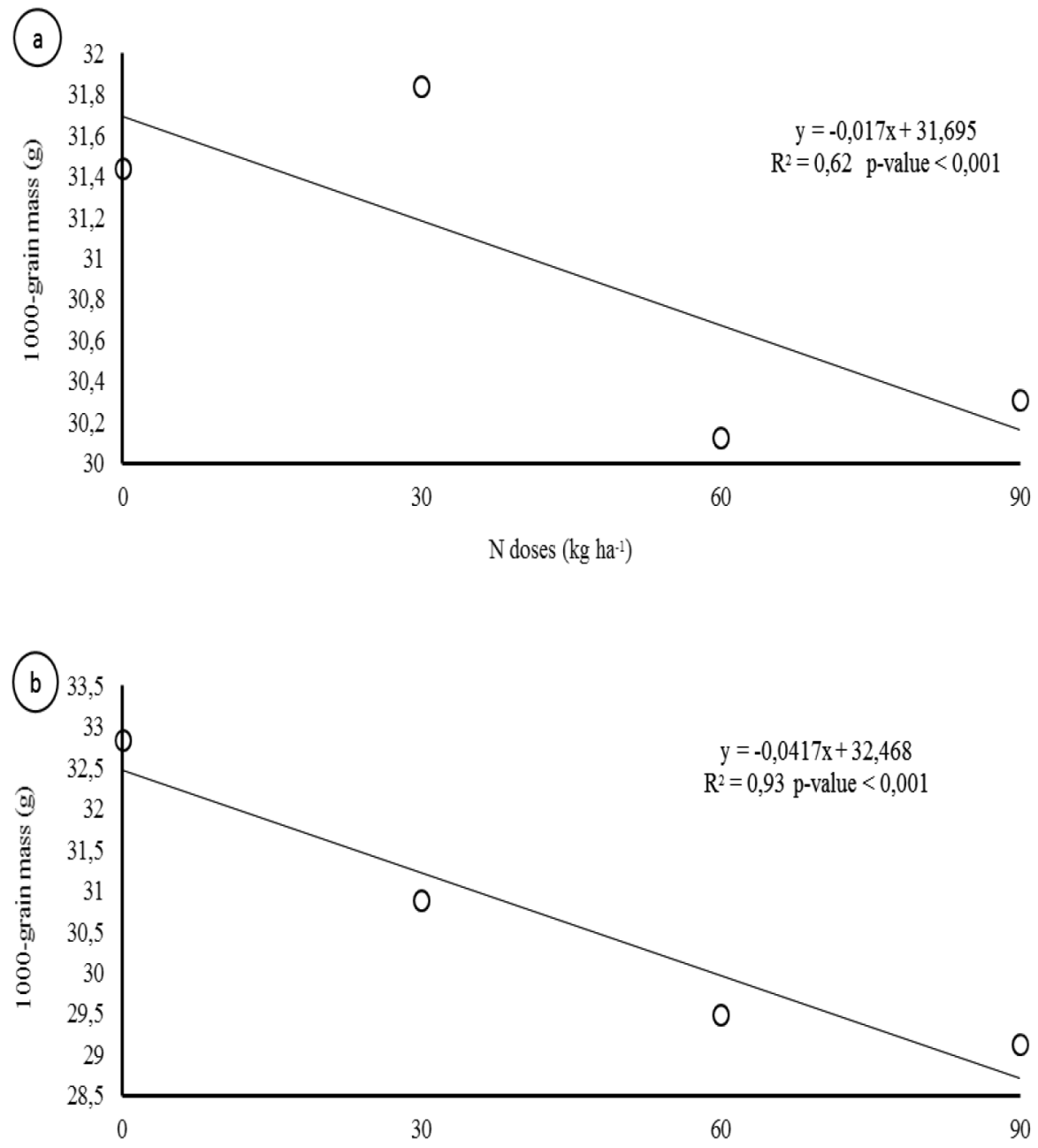

$\mathrm{N}$ doses $(\mathrm{kg} \mathrm{ha-1)}$

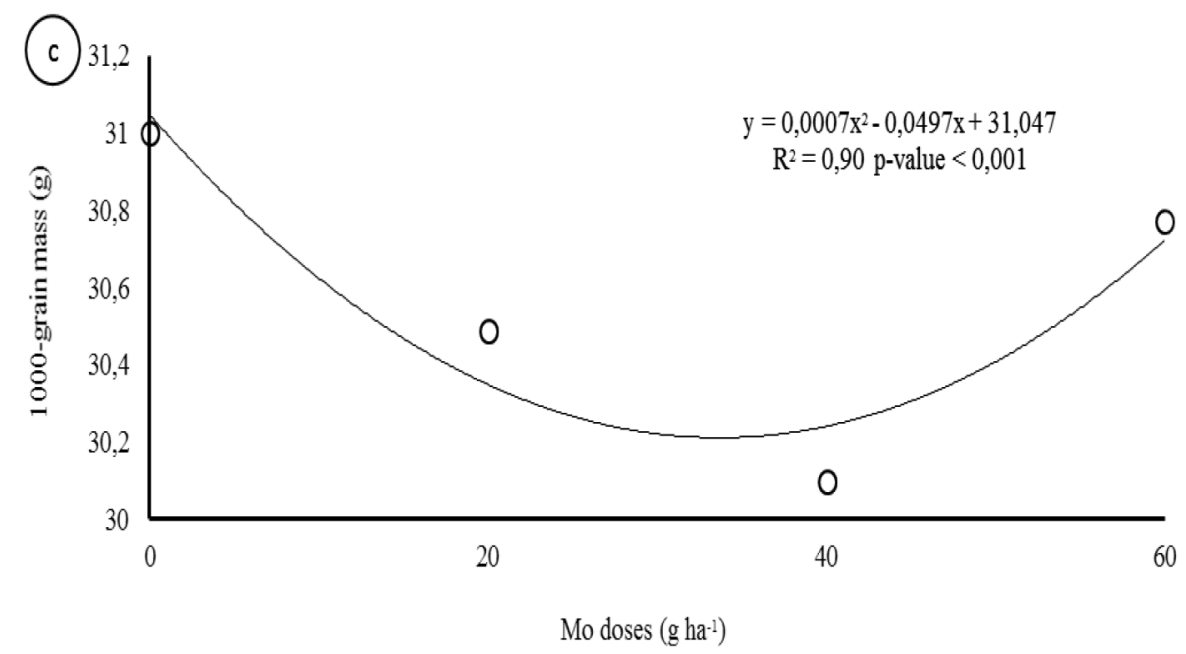


Figure 4. Hectoliter weight (HW) of cultivar CD 150 in response to nitrogen (N) doses applied to the soil cover (a). The HW of grains of cultivar CD 150 at different doses of molybdenum (Mo) applied via leaves in response to $\mathrm{N}$ doses (b) and in different $\mathrm{N}$ doses in response to Mo doses applied via leaves (c). Londrina-PR, 2013 and 2014.
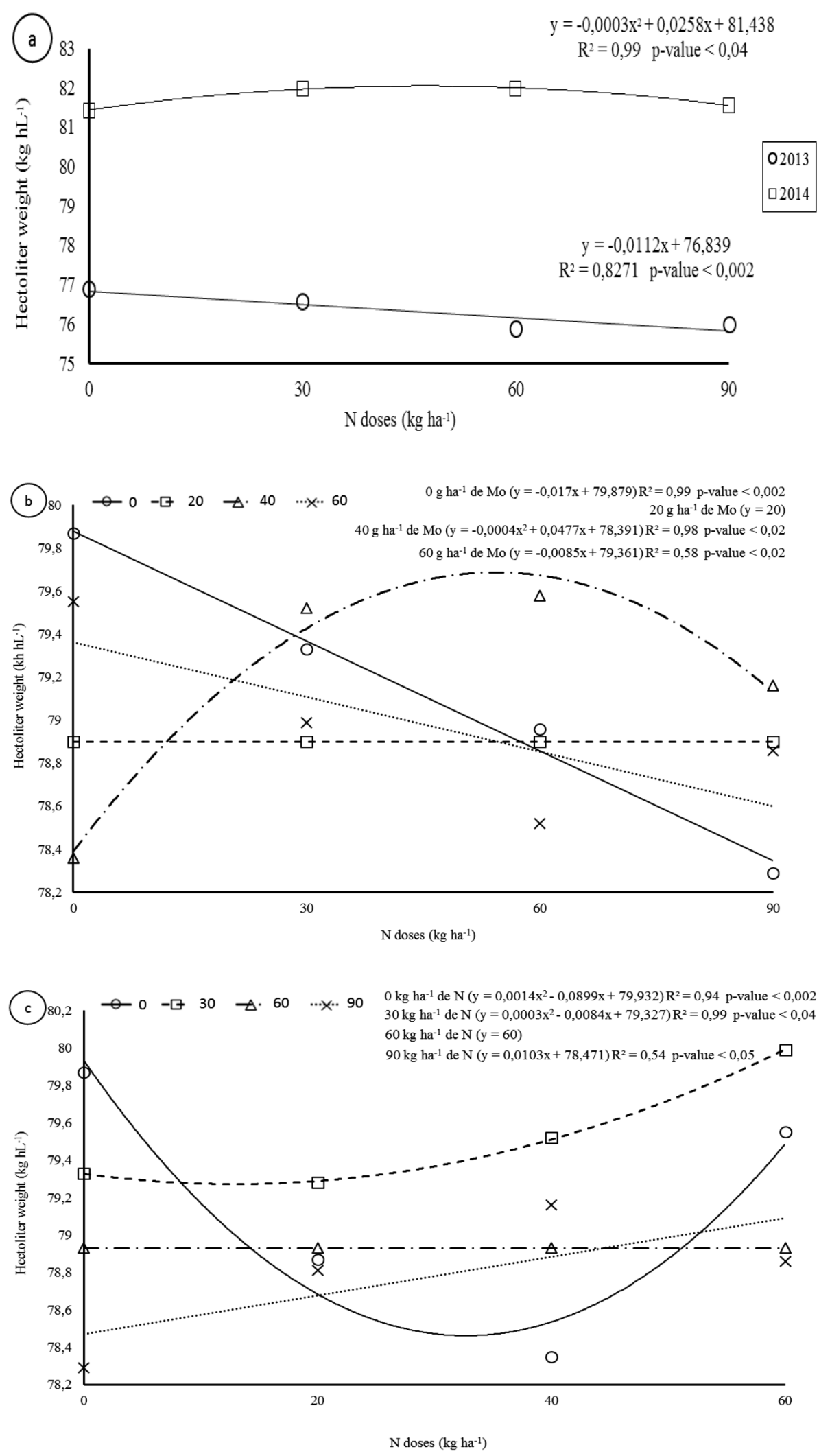
According to Teixeira Filho et al. (2010), rains over the mature culture may explain the reduction of HW and, consequently, the quantity of grains. This occurred due to high respiratory intensity, associated with the consumption of accumulated reserves, induced by the absorption of water by grains soon after the maturation was complete (FRANCESCHI et al., 2009).

For cultivar CD 150, the fertilizer treatments via the leaves with 0 and $60 \mathrm{~g} \mathrm{ha}^{-1}$ of Mo presented a linear decrease in $\mathrm{HW}$ with an increase of $\mathrm{N}$ doses. However, at $20 \mathrm{~g} \mathrm{ha}^{-1}$ of Mo fertilizer there was no response to $\mathrm{N}$ doses. The dose of $40 \mathrm{~g} \mathrm{ha}^{-1}$ of Mo followed a quadratic function, with a maximum value of HW (79.81 $\left.\mathrm{kg} \mathrm{hL}^{-1}\right)$ observed at a dose of $59.62 \mathrm{~kg} \mathrm{ha}^{-1}$ of N (Figure 4b).

There was a linear increase in HW with the increment of Mo at a dose of $90 \mathrm{~kg} \mathrm{ha}^{-1}$ of $\mathrm{N}$. On the other hand, the doses of 0 and $30 \mathrm{~kg} \mathrm{ha}^{-1}$ of $\mathrm{N}$ followed a quadratic function, with the minimum points (78.49 $\mathrm{kg} \mathrm{hL}^{-1}$ and $\left.79.27 \mathrm{~kg} \mathrm{hL}^{-1}\right)$ obtained at doses of $32.1 \mathrm{~g} \mathrm{ha}^{-1}$ and $14 \mathrm{~g} \mathrm{ha}^{-1}$ of Mo, respectively. A dose of $60 \mathrm{~kg} \mathrm{ha}^{-1}$ of $\mathrm{N}$ did not respond to increments of Mo (Figure 4c).

The increase in $\mathrm{N}$ concentration for the treatments without Mo fertilizer caused a linear reduction of HW (Figure 4b). Similarly, Taiz and Zeiger (2009) reported that the lack of Mo decreased the production of nitrate reductase, causing an accumulation of nitrate in the plant and smaller development, which were affected by the reduction in assimilation of $\mathrm{N}$. It was also observed that the increment of Mo doses for the treatments without $\mathrm{N}$ fertilizer reduced the value of the HW until the minimum point of $78.49 \mathrm{~kg} \mathrm{hL}^{-1}$ (Figure 4c). Taiz and Zeiger (2009) elucidated that this may have occurred due to an insufficient transference of $\mathrm{N}$, required for the nitrate reductase enzyme to start the process of assimilation of $\mathrm{N}$ by the plant.

For the cultivar Quartzo, the HW in both years decreased linearly with the increment of $\mathrm{N}$ doses in the soil cover and Mo doses applied via leaves (Figure $5 \mathrm{a}$ and $5 \mathrm{~b})$. The controls $\left(0 \mathrm{~kg} \mathrm{ha}^{-1}\right.$ of $\mathrm{N}$ and $0 \mathrm{~g} \mathrm{ha}^{-1}$ of Mo) showed the highest averages for this characteristic, 76.5 and $76.2 \mathrm{~kg} \mathrm{hL}^{-1}$, respectively. This decrease in the HW was associated with the reduction of the TGM values and an increase in GNPE observed in this cultivar, in addition to the possible increase of number of grains per area, in the two agricultural years. Similar results were found by Prando et al. (2012), who reported that the lower HW obtained was due to the increase in the number of ears or grains per area, which increased the competition for photoassimilates, hindering grain filling.

The wheat cultivars expressed different responses to managing techniques, in particular to $\mathrm{N}$ fertilizer (KEGLER; MOURÃO, 2011). Biudes et al. (2009) described the difference in performance between genotypes cultivated at the same site, as well as significant interactions with other production factors, such as environment (site, year, and sowing season) and management. These authors reported that the cultivation environment, as well as its interaction with management and genotype, may have influenced culture growth and development and consequently established the production potential, according to whether they were subjected to better or worse climate conditions during the phenological cycle of the plants. According to Silva et al. (2014), understanding the relation between environmental conditions of cultivation sites and the production performance of cultivars is essential to attain satisfactory levels of productivity.

The higher GNPE in cultivar Quartzo (Figure 2b) was probably the characteristic that most affected the difference in HW between cultivars, since the observed weight for the cultivar CD 150 (> $78 \mathrm{~kg}$ $\mathrm{hL}^{-1}$ ) (Figure 4) was greater than for the cultivar Quartzo (Figure 5). 
Figure 5. Hectoliter weight of cultivar Quartzo in response to nitrogen doses applied to the soil cover (a) and in response to molybdenum doses applied via leaves (b). Londrina-PR, 2013 and 2014.

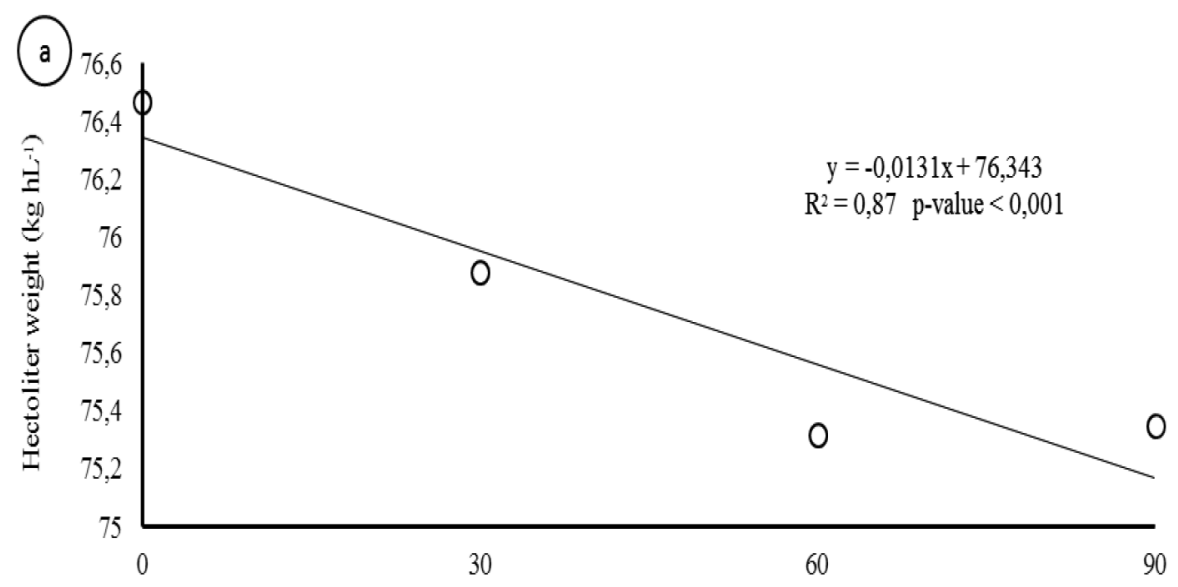

$\mathrm{N}$ doses $(\mathrm{kg}$ ha-1)

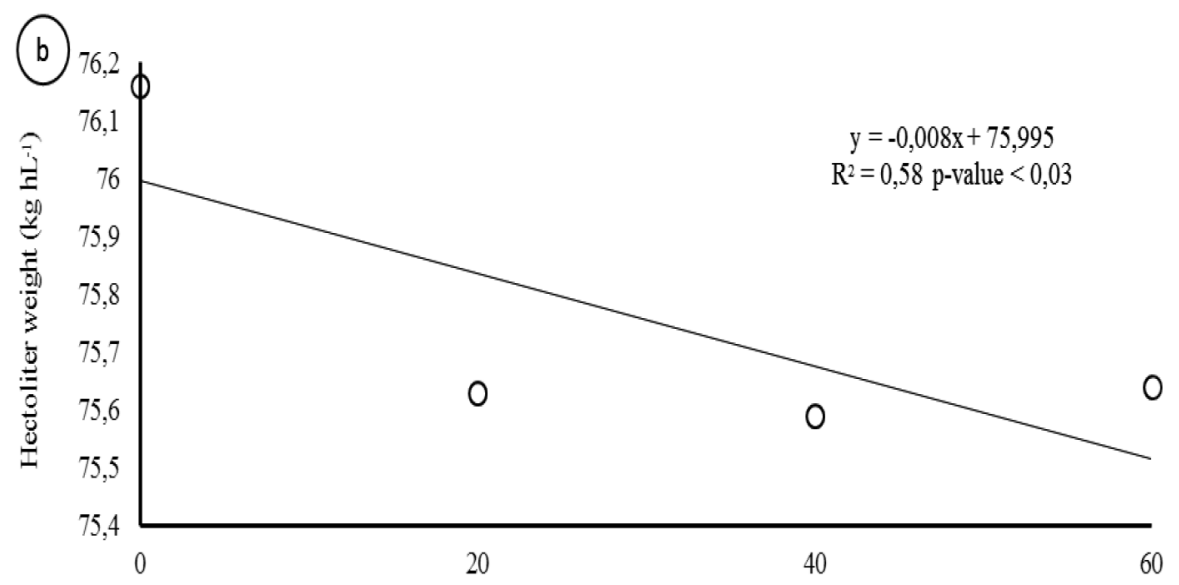

Mo doses (g ha-1)

In the two agricultural harvests, both cultivars presented similar responses for PROD, with a positive linear relationship observed for this characteristic, with yields of $2249.22 \mathrm{~kg} \mathrm{ha}^{-1}$ and $2123.90 \mathrm{~kg} \mathrm{ha}^{-1}$ at the highest dose used $\left(90 \mathrm{~kg} \mathrm{ha}^{-1}\right.$ of N) for cultivars CD 150 and Quartzo, respectively (Figure 6a and 6b). In order to obtain high yields of wheat grains it is essential to use genotypes with high production potential and to use management techniques such as $\mathrm{N}$ fertilizer application in appropriate seasons and quantities (COSTA et al., 2013). According to Soratto et al. (2007), due to its multiple roles in the plant, $\mathrm{N}$ is able to change the yield component of cultures and positively influence the productivity of grains; this was achieved for both cultivars in this study.

The data on the grain yield found in the present work corroborates that obtained by Prando et al. (2012), who worked with three genotypes of wheat (cultivars BRS 208, BRS Pardela, and lineage IWT $04008)$ and four doses of $\mathrm{N}(0,40,80$, and $120 \mathrm{~kg}$ $\mathrm{ha}^{-1}$ ) applied to the soil cover. However, Teixeira Filho et al. (2010) assessed the influence of doses and sources of $\mathrm{N}$ in two agricultural years (2006 
and 2007), on the production and productivity components of wheat, and observed that $\mathrm{N}$ doses followed the quadratic function with maximum productivity being reached at applications of 121 and $122 \mathrm{~kg} \mathrm{ha}^{-1}$ of $\mathrm{N}$, respectively. The differences between results found by these authors and those of this study are probably due to the distinct edaphoclimatic conditions of cultivation sites.
In the work by Teixeira Filho et al. (2010) these were regions at lower latitudes and altitudes, characterized by higher temperatures and solar radiation, utilization of irrigation systems, and different cultivars that presented different genetic characteristics and production potential. In the present work, it was not possible to determine the maximum agronomical yield of the culture according to increments in $\mathrm{N}$ doses.

Figure 6. Productivity of grains from the wheat culture, cultivars CD 150 (a) and Quartzo (b) in response to nitrogen doses applied to the soil cover. Londrina-PR, 2013 and 2014.
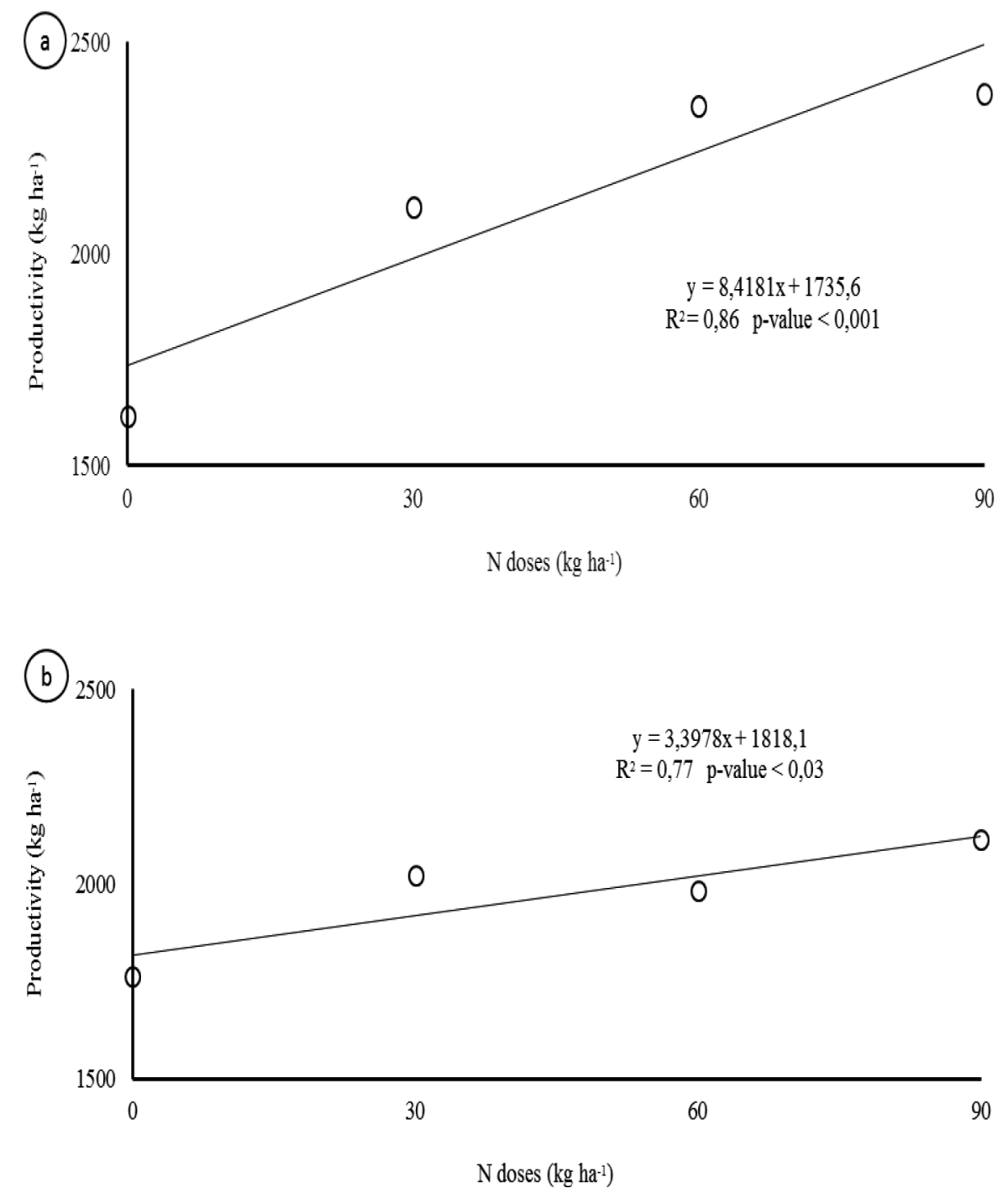


\section{Conclusions}

The application of $\mathrm{N}$ fertilizer to soil cover did not benefit the production component of either of the cultivars of wheat, except for the GNPE in the Quartzo cultivar that increased with the increment of $\mathrm{N}$ doses in the two harvests. The increase in $\mathrm{N}$ fertilizer raised productivity of wheat grains for both cultivars.

The application of Mo via leaves did not benefit the yield or productivity components of wheat grains of either cultivar.

The interaction between the doses of $\mathrm{N}$ and Mo affected the HW, and this was reduced in the absence of one of these fertilizers.

\section{References}

BIUDES, G. B.; CAMARGO, C. E. O.; FERREIRA FILHO, A. W. P.; PETTINELLI JÚNIOR, A.; FOLTRAN, D. E.; CASTRO, J. L.; AZEVEDO FILHO, J. A. Adaptabilidade e estabilidade de linhagens diaplóides de trigo. Bragantia, Campinas, v. 68, n. 1, p. 63-74, 2009.

BULL, L. T. Nutrição do milho. In: BULL, L. T.; CANTARELLA, H. Cultura do milho: fatores que afetam a produtividade. Piracicaba: POTAFÓS, 1993. p. 71-104.

CAZETTA, D. A.; FORNASIERI FILHO, D.; ARF, O. Respostas de cultivares de trigo e triticale ao nitrogênio no sistema de plantio direto. Cientifica, Joboticabal, v. 35, n. 2, p. 155-165, 2007.

CUNHA, G. R.; CAIERÃO, E. (Ed.). Informações técnicas para trigo e triticale - Safra 2015: VIII Reunião da comissão brasileira de pesquisa de trigo e triticale. Canela: Embrapa Trigo, 2015. 230 p.

COSTA, L.; ZUCARELI, C.; RIEDE, C. R. Parcelamento da adubação nitrogenada no desempenho produtivo de genótipos de trigo. Revista Ciência Agronômica, Fortaleza, v. 44, n. 2, p. 215-224, 2013.

EMPRESA BRASILEIRA DE PESQUISA AGROPECUÁRIA - EMBRAPA. Centro Nacional de Pesquisa de Solos. Sistema brasileiro de classificação de solos. 7. ed. Rio de Janeiro: Embrapa, 2006. 306 p.

ESPINDULA, M. C.; ROCHA, V. S.; SOUZA, M. A.; GROSSI, J. A. S.; SOUZA, L. T. Doses e formas de aplicação de nitrogênio no desenvolvimento e produção da cultura do trigo. Ciência e Agrotecnologia, Lavras, v. 34, n. 6, p. 1404-1411, 2010.
FERREIRA, A. C. B.; ARAÚJO, G. A. A.; CARDOSO, A. A.; FONTES, P. C. R.; VIEIRA, C. Características agronômicas do feijoeiro em função do molibdênio contido na semente e da sua aplicação via foliar. Acta Scientiarum. Agronomy, Maringá, v. 25, n. 1, p. 65-72, 2003.

FERREIRA, A. C. B.; ARAÚJO, G. A. A.; PEREIRA, P. R. G.; CARDOSO, A. A. Características agronômicas e nutricionais do milho adubado com nitrogênio, molibdênio e zinco. Scientia Agricola, Piracicaba, v. 58, n. 1, p. 131-138, 2001.

FRANCESCHI，L.; BENIN，G.; GUARIENTI， E.; MARCHIORO, V. S.; MARTIN, T. N. Fatores précolheita que afetam a qualidade tecnológica de trigo. Ciência Rural, Santa Maria, v. 39, n. 5, p. 1624-1631, 2009.

KEGLER, W. F.; MOURÃO, A. P. M. Adubação nitrogenada aplicada em cobertura na cultura do trigo na região Sudoeste do Paraná. Cultivando o Saber, Cascavel, v. 4, n. 1, p. 62-72, 2011.

MARSCHNER, H. Mineral nutrition of higher plants. London: Academic Press Limited, 1995. 889 p.

MARTENS, D. C.; WESTERMANN, D. T. Fertilizers application for correcting micronutrients deficiencies. In: MORTVEDT, J. J.; COX, F. R.; SHUMAN, L. M.; WELCH, R. M. (Ed.). Fertilizers applications for correcting micronutriente deficiencies: micronutrients in agriculture. $2^{\text {th }}$ ed. Madison: Soil Science Society of America, 1991. p. 549-592.

MARTINI JUNIOR, P. C.; FERREIRA, D. T. L.; MOREIRA, G. C. Características agronômicas da cultivar de trigo cd 114 submetido à aplicação nitrogenada em cobertura. Cultivando o Saber, Cascavel, v. 4, n. 3, p. 158-172, 2011.

MEGDA, M. M.; BUZETTI, S.; ANDREOTTI, M.; TEIXEIRA FILHO, M. C. M.; VIEIRA, M. X. Resposta de cultivares de trigo ao nitrogênio em relação às fontes e épocas de aplicação sob plantio direto e irrigação por aspersão. Ciência e Agrotecnologia, Lavras, v. 33, n. 4, p. 1055-1060, 2009.

PERUZZO, G. Nitrogênio no seu trigo. Revista Cultivar Grandes Culturas, Pelotas, v. 2, n. 16, p. 20-22, 2000.

PIETRO-SOUZA, W.; BONFIM-SILVA, E. M.; SCHLICHTING, A. F.; SILVA, M. C. Desenvolvimento inicial de trigo sob diferentes doses de nitrogênio em latossolo vermelho do cerrado. Revista Brasileira de Engenharia Agrícola e Ambiental, Campina Grande, v. 17, n. 6, p. 575-580, 2013.

PRANDO, A. M.; ZUCARELI, C.; FRONZA, V.; BASSOI, M. C.; OLIVEIRA, F. A. Formas de ureia 
e doses de nitrogênio em cobertura no desempenho agronômico de genótipos de trigo. Semina: Ciências Agrárias, Londrina, v. 33, n. 2, p. 621-632, 2012.

PRANDO, A. M.; ZUCARELI, C.; FRONZA, V.; OLIVEIRA, F. A.; OLIVEIRA JÚNIOR, A. O. Características produtivas do trigo em função de fontes e doses de nitrogênio. Pesquisa Agropecuária Tropical, Goiânia, v. 43, n. 1, p. 34-41, 2013.

SILVA, A. C.; MORAIS, O. M.; SANTOS, J. L.; ARÊDE, L. O.; SILVA, P. B. Componentes de produção, produtividade e qualidade de sementes de feijão-caupi em Vitória da Conquista, BA. Revista Brasileira de Agroambiente, Boa Vista, v. 8, n. 3, p. 327-335, 2014.

SORATTO, R. P.; CARDOSO, S. M.; SILVA, A. H.; COSTA, T. A. M.; PEREIRA, M.; CARVALHO, L. A. Doses e épocas de aplicação de nitrogênio em cobertura na cultura do painço (Panicum miliaceum L.). Ciência e Agrotecnologia, Lavras, v. 31, n. 6, p. 1661-1667, 2007.

SOUZA, J. L. M.; GERSTEMBERGER, E.; ARAUJO, M. A. Calibração de modelos agrometeorológicos para estimar a produtividade da cultura do trigo, considerado sistemas de manejo do solo, em Ponta Grossa-PR. Revista Brasileira de Meteorologia, Rio de Janeiro, v. 28, n. 4, p. 409-418, 2013.

TAIZ, L.; ZEIGER, E. Fisiologia vegetal. Porto Alegre: Artmed, 2009. $819 \mathrm{p}$.
TEIXEIRA FILHO, M. C. M. T.; BUZETTI, S.; ANDREOTTI, M.; ARF, O.; BENETT. C. G. S. Doses, fontes e épocas de aplicação de nitrogênio em trigo irrigado em plantio direto. Pesquisa Agropecuária Brasileira, Brasília, v. 45, n. 8, p. 797-804, 2010.

TEIXEIRA FILHO, M. C. M.; BUZETTI, S.; ALVAREZ, R. C. F.; FREITAS, J. G.; ARF, O.; SÁ, M. E. Resposta de cultivares de trigo irrigados por aspersão ao nitrogênio em cobertura na região do Cerrado. Acta Scientiarum. Agronomy, Maringá, v. 29, n. 3, p. 421-425, 2007.

THEAGO, E. Q.; BUZETTI, S.; TEIXEIRA FILHO, M. C. M.; ANDREOTTI, M.; MEGDA, M. M.; BENETT, C. G. S. Doses, fontes e épocas de aplicação de nitrogênio influenciando teores de clorofila e produtividade do trigo. Revista Brasileira de Ciência do Solo, Campinas, v. 38, n. 6, p. 1826-1835, 2014.

YANO, G. T.; TAKAHASHI, H. W.; WATANABE, T. S. Avaliação de fontes de nitrogênio e épocas de aplicação em cobertura para o cultivo do trigo. Semina: Ciências Agrárias, Londrina, v. 26, n. 2, p. 141-148, 2005.

ZOZ, T.; STEINER, F.; TESTA, J. V. P.; SEIDEL, E. P.; FEY, R.; CASTAGNARA, D. D.; ZOZ, A. Foliar fertilization with molybdenum in wheat. Semina: Ciências Agrárias, Londrina, v. 33, n. 2, p. 633-638, 2012. 